\title{
Fermentative Bio-Hydrogen Production of Food Waste in the Presence of Different Concentrations of Salt $\left(\mathrm{Na}^{+}\right)$and Nitrogen
}

\author{
Pul-eip Lee, Yuhoon Hwang, and Tae-jin Lee* \\ Department of Environmental Engineering, Seoul National University of Science and Technology, Seoul 01811, Republic of Korea
}

\author{
Received: August 16, 2018 \\ Revised: November 20, 2018 \\ Accepted: November 30, 2018 \\ First published online \\ December 7, 2018 \\ *Corresponding author \\ Phone: +82-2-970-6614 \\ Fax: +82-2-971-5776; \\ E-mail: leetj@seoultech.ac.kr \\ pISSN 1017-7825, eISSN 1738-8872 \\ Copyright(C) 2019 by \\ The Korean Society for Microbiology \\ and Biotechnology
}

Fermentation of food waste in the presence of different concentrations of salt $\left(\mathrm{Na}^{+}\right)$and ammonia was conducted to investigate the interrelation of $\mathrm{Na}^{+}$and ammonia content in biohydrogen production. Analysis of the experimental results showed that peak hydrogen production differed according to the ammonia and $\mathrm{Na}^{+}$concentration. The peak hydrogen production levels achieved were $(97.60,91.94$, and 49.31) $\mathrm{ml} / \mathrm{g}$ COD at (291.41, 768.75, and $1,037.89) \mathrm{mg}-\mathrm{N} / \mathrm{L}$ of ammonia and $(600,1,000$, and 4,000$) \mathrm{mg}-\mathrm{Na}^{+} / \mathrm{L}$ of salt concentration, respectively. At peak hydrogen production, the ammonia concentration increased along with increasing salt concentration in the medium. This means that for peak hydrogen production, the $\mathrm{C} / \mathrm{N}$ ratio decreased with increasing salt content in the medium. The butyrate/acetate $(\mathrm{B} / \mathrm{A})$ ratio was higher in proportion to the bio-hydrogen production (r-square: 0.71, $p$-value: 0.0006). Different concentrations of $\mathrm{Na}^{+}$and ammonia in the medium also produced diverse microbial communities. Klebsiella sp., Enterobacter sp., and Clostridium sp. were predominant with high bio-hydrogen production, while Lactococcus sp. was found with low bio-hydrogen production.

Keywords: Ammonia, salt, bio-hydrogen, dark fermentation

\section{Introduction}

Hydrogen production technologies have gained significant attention due to the increased demand for hydrogen as an energy carrier [1]. The only by-product of combustion produced is hydrogen, making it a pollutant-free, alternative form of energy. Hydrolysis of chemical hydrides or metals has recently received attention as an optimal method for the production of hydrogen [2-4]. However, other chemical hydrogen production methods, such as steam reforming of hydrocarbons and partial oxidation of combustible fossil fuels, are energy intensive and require high temperature, resulting in the release of carbon dioxide and other pollutants as by-products [5]. Under these circumstances, biological hydrogen production from biomass appears to be one of the promising ways to replace traditional methods, as it can produce hydrogen competitively under ambient conditions, without causing pollution problems [6, 7].

Hydrogen can be generated through various biological production processes including direct bio-photolysis, indirect bio-photolysis, photofermentation, or dark fermentation [8].
Compared to the other three processes, the dark fermentation process has a high production rate, and much simpler operational requirements $[9,10]$. Dark fermentation does not need light and has a very high evolution rate of hydrogen compared to photosynthetic processes [9]. Valuable by-products and biomass produced in the hydrogen fermentation make dark fermentation more favorable for commercialization $[11,12]$.

Even though dark fermentation of organic waste has high potential to produce bio-hydrogen together with the reduction of waste [13], low bio-hydrogen yield is a bottleneck to its practical application. Further research is needed on optimizing microbial community enrichment or the operational parameters of the reactor, such as $\mathrm{pH}$, salt content, temperature, or $\mathrm{H}_{2}$ partial pressure to improve bio-hydrogen yield [14]. $\mathrm{Na}^{+}$is one of the parameters that affect bio-hydrogen production. It is originally a micronutrient for bacterial growth [15], but it is also related to hydrogen formation based on the $\mathrm{Na}^{+}$gradient in cells. The $\mathrm{Na}^{+}$gradient produced by high extracellular $\mathrm{Na}^{+}$ concentration enhances the reduction of oxidized ferredoxin, 
resulting in a higher concentration of reduced ferredoxin, which favors the formation of $\mathrm{H}_{2}$ [16, 17]. Nevertheless, high $\mathrm{Na}^{+}$concentrations could cause an inhibitory effect on biological hydrogen production because of changes in the metabolic pathway to favor the formation of other metabolites, rather than hydrogen production. [18-19]. Nitrogen is another affecting factor for hydrogen producers, as it is an important component of living matter [20]. Although ammonia nitrogen (from $\mathrm{NH}_{3}$ or $\mathrm{NH}_{4}^{+}$) is an essential nutrient for bacterial growth, it has been reported to be toxic in dark fermentation processes if the concentration is higher than threshold [21, 22]. When $\mathrm{NH}_{3}$ penetrates the cell membrane, it is protonized to $\mathrm{NH}_{4}{ }^{+}$, which destroys the balance in intracellular $\mathrm{pH}$ [23]. But to date, little information is available about variations of bio-hydrogen production caused by the interrelation effect of two or more parameters in the sources.

Food and food processing wastes could be potential feedstock for biological hydrogen production because of the high content of organic matter and nutrients [24]. Food waste contains large portions of carbohydrate, protein, and fat, which can readily be degraded via dark fermentation. However, the composition of food waste is varied depending on its source. Most food waste may be lacking in nitrogen, but some food waste contains high amounts of salt and nitrogen $[17,25]$. Therefore, in order to utilize food waste appropriately as a feedstock for dark fermentation, the effects of salinity or nitrogen content on the activities and metabolic processes of hydrogen production microbes need to be studied.

This study investigated the interrelation of the salt $\left(\mathrm{Na}^{+}\right)$ and ammonia content on the fermentative bio-hydrogen production from food waste. For this purpose, the biohydrogen production efficiency of food waste with different $\mathrm{Na}^{+}$and ammonia regimes was analyzed by a modified Gompertz equation. The formation of Volatile Fatty Acids (VFAs) under different conditions of salt $\left(\mathrm{Na}^{+}\right)$ and ammonia content were also investigated. In addition,

Table 1. Characteristics of collected food waste.

\begin{tabular}{lc}
\hline \multicolumn{1}{c}{ Parameter } & Concentration $(\mathrm{mg} / \mathrm{l})$ \\
\hline Total COD & $321,788 \pm 80,448$ \\
Soluble COD & $201,117 \pm 62,570$ \\
Total Nitrogen(T-N) & $6,491 \pm 292$ \\
Total Phosphorus(T-P) & $397 \pm 9$ \\
Total Carbohydrate & $263,300 \pm 1,571$ \\
Protein & $9,447 \pm 1,158$ \\
$\mathrm{Na}^{+}$ & $19,200 \pm 546$ \\
\hline
\end{tabular}

analysis of the microbial community involved in the fermentative bio-hydrogen production from food waste was conducted by denaturing gradient gel electrophoresis (DGGE) of a PCR-amplified V3 region of $16 \mathrm{~S}$ rDNA.

\section{Materials and Methods}

\section{Microorganisms and Culture}

The return activated sludge from a wastewater treatment plant was used as seed sludge for this study. The synthetic medium [26] contained $15 \mathrm{~g} / \mathrm{l}$ of sucrose, $10 \mathrm{mg} / 1$ of $\mathrm{CaCl}_{2} \cdot 2 \mathrm{H}_{2} \mathrm{O}, 100 \mathrm{mg} / \mathrm{l}$ of $\mathrm{MgSO}_{4} \cdot 7 \mathrm{H}_{2} \mathrm{O}, 10 \mathrm{mg} / 1$ of $\mathrm{NaCl}, 2 \mathrm{~g} / 1$ of $\mathrm{NH}_{4} \mathrm{HCO}_{3}, 1 \mathrm{~g} / 1$ of $\mathrm{KH}_{2} \mathrm{PO}_{4}, 15 \mathrm{mg} / \mathrm{l}$ of $\mathrm{MnSO}_{4} \cdot 7 \mathrm{H}_{2} \mathrm{O}, 10 \mathrm{mg} / \mathrm{l}$ of $\mathrm{NaMoO}_{4} \cdot 2 \mathrm{H}_{2} \mathrm{O}$, and $2.78 \mathrm{mg} / 1$ of $\mathrm{FeCl}_{2}$. The $10 \mathrm{ml}$ of seed sludge was added into $90 \mathrm{ml}$ of the synthetic medium under anaerobic conditions [27]. The initial $\mathrm{pH}$ of the medium in serum bottles was set at 7.0. For the acclimation of seed microflora, the cultures were sequentially transferred from the serum bottles into fresh medium.

\section{Operation of Batch Reactor}

The substrate, or food waste, was obtained from a university cafeteria and was crushed by an electrical blender in an anaerobic glove box filled with nitrogen gas. Table 1 shows the characteristics of the food waste, from which all of the substrates were filtered through a stainless steel sieve (US Mesh No. 10). $\mathrm{NH}_{4} \mathrm{Cl}$ and $\mathrm{NaCl}$ were analytical grade (Ducksan Co., Korea) and used as the nitrogen and $\mathrm{Na}$ source, respectively. Ammonia and $\mathrm{Na}^{+}$ concentrations of the medium were prepared in the range of (100-

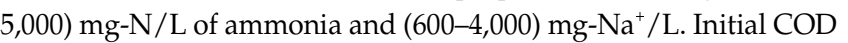
concentration was adjusted to be $10,000 \mathrm{mg} / \mathrm{l}$. The carbon to nitrogen $(\mathrm{C} / \mathrm{N})$ ratio in the feed stock, which ranged (0.75-37.5), was artificially adjusted according to the purpose of the experiment.

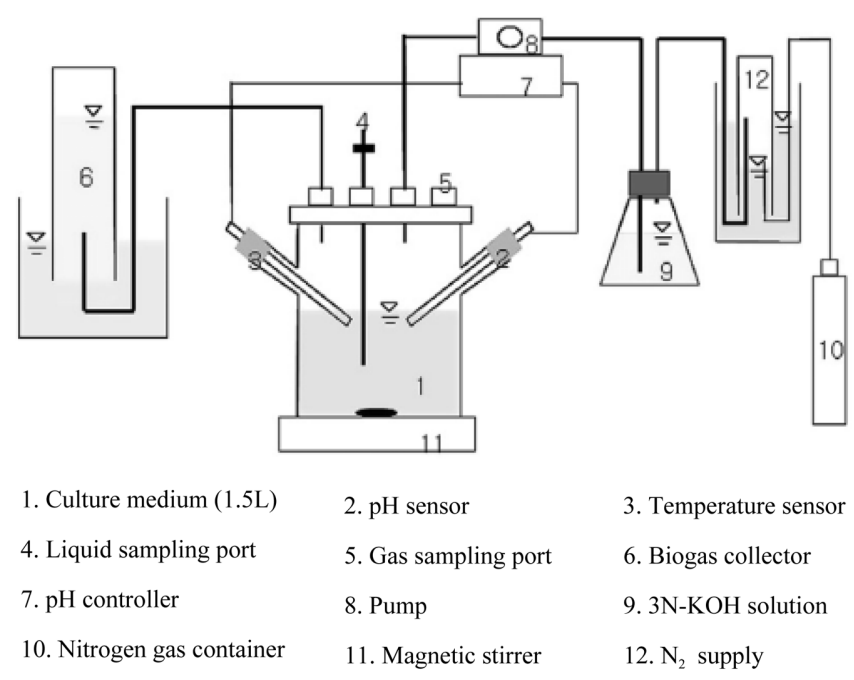

Fig. 1. A sketch of the batch reactor for bio-hydrogen production. 
Biological hydrogen production potential (BHP) tests of food waste were conducted in the batch reactor with a 1.5-L working volume. Fig. 1 is a schematic diagram of the batch reactor, which was stirred at $250 \mathrm{rpm}$ using a magnetic stirrer. The headspace was initially maintained in an anaerobic condition using nitrogen gas. After that, $15 \mathrm{ml}$ of seed solution was added, resulting in an initial volatile suspended solids (VSS) concentration of approximately $10 \mathrm{mg} / \mathrm{l}$. The reactor was kept at $30^{\circ} \mathrm{C}$ in the dark to avoid the growth of photosynthetic bacteria. The $\mathrm{pH}$ of the reactor was kept constant at 5.5 by the addition of $\mathrm{KOH}$ solution [27]. The generated biogas was collected by a gas collector on the reactor. At regular intervals, $0.2 \mathrm{ml}$ of headspace gas was withdrawn for analysis.

\section{Analytical Methods}

The hydrogen and $\mathrm{CO}_{2}$ concentrations were analyzed using a gas chromatography (GOW-MAC, USA), equipped with a thermal conductivity detector (TCD). The applied separation column and carrier gas were a $6^{\prime} \times 1 / 8^{\prime \prime}$ stainless steel SS $350 \mathrm{~A}$ Molsieve $13 \mathrm{X}$ and nitrogen gas at a flow rate of $30 \mathrm{ml} / \mathrm{min}$, respectively. The injection port, column, and detector temperature were 80,100 , and $100^{\circ} \mathrm{C}$, respectively.

The VSS for cell concentration, total or soluble chemical oxygen demand (COD), total nitrogen (T-N), and total phosphorus (T-P) were analyzed according to the standard methods [28, 29]. Carbohydrate and protein concentrations were measured by the phenol-sulfuric acid and modified Lowry methods, respectively $[29,30]$. High-performance liquid chromatography (KNAUER, Germany) and a UV detector operating at $210 \mathrm{~nm}$ were used for VFAs (butyrate, acetate, lactate, and propionate) analysis. The column was a Supelcogel C-610H (130 mm $\times 7.8 \mathrm{~mm}$ ID). Ammonia and sodium concentrations were measured using ion chromatography (Metrohm compact 761, Switzerland).

\section{Model Development}

The cumulative bio-hydrogen production of the food waste was analyzed by the modified Gompertz equation (Eq. (1)) [27]

$$
M=P \cdot \exp \left\{-\exp \left[\frac{R \cdot e}{P}(\lambda-t)+1\right]\right\}
$$

where, $\mathrm{M}$ and $\mathrm{P}$ are the cumulative hydrogen production (in $\mathrm{ml}$ ) and the hydrogen production potential $(\mathrm{ml})$, respectively. $\mathrm{R}$ is the maximum hydrogen production rate $(\mathrm{ml} / \mathrm{h}), \lambda$ is the lag-phase time (h), e is $\exp (1)=2.718$, and $t$ is the incubation time (h).

\section{Microbial Community Analysis}

PCR was performed to assess the composition of the microbial community. DNA was extracted from microorganisms using the PowerSoil DNA Isolation Kit (MO BIO Laboratories, Inc., USA). The eluted DNA from the microorganisms in the samples was reamplified by PCR with the forward primer 341f (5'-CCTACG GGAGGCAGCAG- $\left.3^{\prime}\right)$ and the reverse primer $518 \mathrm{r}$ (5'-ATTACC
GCGGCTGCTGG-3') [31]. The quality of the DNA samples was analyzed by DGGE [32]. Sequencing analyses of the bands on the gradient gel were conducted for the closest reference microorganisms in the GenBank database using the BLAST program [33].

\section{Results and Discussion}

\section{Bio-Hydrogen Production by Various Salt $\left(\mathrm{Na}^{+}\right)$Concentrations}

A number of studies have reported the negative effect of $\mathrm{Na}^{+}$and ammonia on hydrogen production with mixed cultures [17, 34-38]. High $\mathrm{Na}^{+}$concentrations exceeding the threshold level may result in the formation of other metabolites than hydrogen, which cause the suppression of bio-hydrogen production [19]. The low cell growth caused by this utilization of energy finally results in low hydrogen production [17]. High concentrations of ammonia have also been reported to be toxic on anaerobic digestion processes [37].

Several studies $[16,21,38]$ reported that ammonia concentrations resulted in shifts to generate varying concentrations of soluble metabolites by altering metabolic pathways of the dark fermentation process. These endproducts could also have a suppressive effect on biohydrogen production. Such a strategy as dilution of the reactor contents below suppressive threshold concentration, or microbial acclimation to the inhibitors prior to the fermentation process, could be proposed to reduce the inhibition of bio-hydrogen production. To optimize the strategies, it is worthwhile evaluating the interrelation of ammonia and $\mathrm{Na}^{+}$concentrations on bio-hydrogen production, rather than evaluating the influence of independent factors.

The effects of $\mathrm{Na}^{+}$and ammonia concentrations on biohydrogen production were investigated with medium containing in the range of $(200-5,000) \mathrm{mg}-\mathrm{N} / \mathrm{L}$ of ammonia and $(600-4,000) \mathrm{mg}-\mathrm{Na}^{+} / \mathrm{L}$. The hydrogen production curves over time were analyzed by Eq. (1). Table 2 lists the hydrogen production rates against the $\mathrm{Na}^{+}$and ammonia concentrations.

Fig. 2 plots the hydrogen production potential rate $\left(\mathrm{P}_{\mathrm{h}}\right)$ against the ammonia concentration in the presence of $\mathrm{Na}^{+}$, and the relationship was obtained using a Weibull 5parameter equation $\left(r^{2}=0.97\right.$, Sigma Plot 2006 Systat Software Inc., USA). Analysis of the data showed that peak hydrogen production differed according to the ammonia and $\mathrm{Na}^{+}$concentrations in the medium. The peak hydrogen production levels achieved were (97.60, 91.94, and 49.31) $\mathrm{ml} / \mathrm{g}$ COD at $(291.41,768.75$, and 1,037.89) $\mathrm{mg}-\mathrm{N} / \mathrm{L}$ of

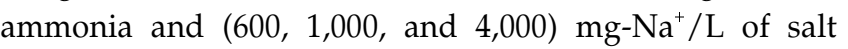
concentration, respectively. Since the initial COD value 
Table 2. Parameter values for bio-hydrogen gas with different salt $\left(\mathrm{Na}^{+}\right)$and ammonia concentrations in the food waste.

\begin{tabular}{|c|c|c|c|c|c|c|c|}
\hline \multirow{2}{*}{$\begin{array}{l}\text { Sodium concentration } \\
\qquad\left(\mathrm{mg}-\mathrm{Na}^{+} / \mathrm{L}\right)\end{array}$} & \multirow{2}{*}{$\begin{array}{l}\text { Ammonia concentration } \\
(\mathrm{mg}-\mathrm{N} / \mathrm{L})\end{array}$} & \multicolumn{2}{|c|}{ Production potential } & \multirow{2}{*}{$\begin{array}{c}\mathrm{H}_{2} \text { yield } \\
\left(\mathrm{ml} \mathrm{H}_{2} / \mathrm{gCOD}\right)\end{array}$} & \multicolumn{2}{|l|}{ Production rate } & \multirow{2}{*}{$\mathrm{r}^{2}$} \\
\hline & & $\mathrm{P}_{\mathrm{h}}(\mathrm{ml})$ & $p$-value & & $\mathrm{R}_{\mathrm{h}}(\mathrm{ml} / \mathrm{g}$ dry wt biomass $/ \mathrm{h})$ & $p$-value & \\
\hline \multirow[t]{8}{*}{600} & 100 & 226.86 & $<0.0001$ & 14.38 & 13.83 & 0.0017 & 0.98 \\
\hline & 150 & 344.64 & $<0.0001$ & 26.37 & 15.68 & 0.0009 & 0.98 \\
\hline & 200 & $1,268.67$ & $<0.0001$ & 102.00 & 83.43 & $<0.0001$ & 0.99 \\
\hline & 350 & $1,416.06$ & $<0.0001$ & 93.33 & 94.29 & 0.0107 & 0.97 \\
\hline & 600 & 848.27 & $<0.0001$ & 59.64 & 18.14 & $<0.0001$ & 0.98 \\
\hline & 1,500 & 379.89 & $<0.0001$ & 19.64 & 21.83 & 0.0011 & 0.98 \\
\hline & 3,000 & 269.21 & $<0.0001$ & 12.14 & 13.95 & 0.0265 & 0.96 \\
\hline & 5,000 & 203.88 & $<0.0001$ & 13.41 & 25.52 & 0.0061 & 0.98 \\
\hline \multirow[t]{4}{*}{1,000} & 200 & 775.20 & $<0.0001$ & 51.97 & 36.37 & 0.0018 & 0.98 \\
\hline & 600 & $1,309.50$ & $<0.0001$ & 77.11 & 55.60 & 0.0769 & 0.92 \\
\hline & 1,500 & 579.57 & $<0.0001$ & 37.44 & 41.11 & $<0.0001$ & 0.99 \\
\hline & 3,000 & 291.53 & $<0.0001$ & 16.86 & 20.74 & 0.0193 & 0.97 \\
\hline \multirow[t]{6}{*}{4,000} & 100 & 514.28 & $<0.0001$ & 41.85 & 19.12 & $<0.0001$ & 0.99 \\
\hline & 200 & 495.29 & $<0.0001$ & 39.47 & 30.91 & 0.0767 & 0.98 \\
\hline & 600 & 673.73 & $<0.0001$ & 65.14 & 22.87 & 0.0148 & 0.97 \\
\hline & 1,500 & 661.55 & $<0.0001$ & 40.45 & 27.19 & 0.0091 & 0.98 \\
\hline & 3,000 & 340.08 & $<0.0001$ & 26.91 & 4.23 & 0.0007 & 0.96 \\
\hline & 5,000 & 241.90 & $<0.0001$ & 18.09 & 14.50 & 0.0259 & 0.96 \\
\hline
\end{tabular}

was $10,000 \mathrm{mg} / \mathrm{l}, \mathrm{C} / \mathrm{N}$ ratios at peak hydrogen production were $12.87,4.88$, and 3.61 , respectively. This means that the presence of higher salt $\left(\mathrm{Na}^{+}\right)$content reduced the optimum

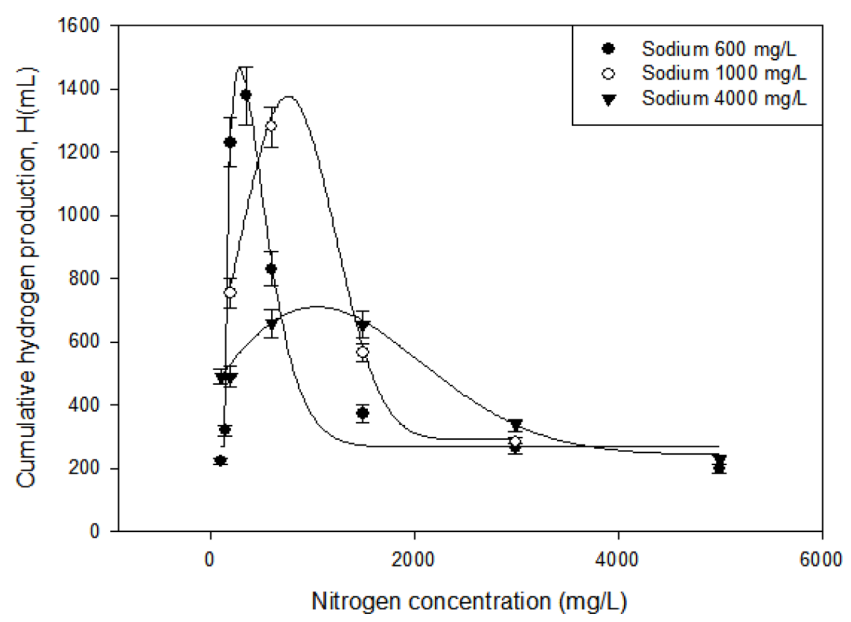

Fig. 2. Bio-hydrogen production profile in the various concentrations of ammonia and sodium $\left(\mathrm{Na}^{+}\right)$.

The initial concentration of COD at each mode was $10,000 \mathrm{mg} / 1$. Symbols on the graph represent average values, of three experimental data sets. Error bar of experimental data was conducted, using Sigma Plot software.
$\mathrm{C} / \mathrm{N}$ ratio for bio-hydrogen production. An earlier study [25] reported that peak hydrogen productivity reached a $\mathrm{C} / \mathrm{N}$-ratio of 47 , but this experimental result implies that to maximize the production of bio-hydrogen, inhibition factors must be considered, because the $\mathrm{C} / \mathrm{N}$ ratio could change according to the $\mathrm{Na}^{+}$concentration, as shown above.

Hydrogen production and substrate consumption could be inhibited in the presence of toxic substances while different degrees of inhibition would be shown, depending on the microbial species [15, 39, 40]. Our experimental results show increasing peak hydrogen production with lower sodium concentration. A previous study [41] reported that NADH-ferredoxin oxidoreductase activity could be enhanced in the presence of the proper concentration of $\mathrm{Na}^{+}$for hydrogen production. This result suggests that biohydrogen production using food waste as a substrate could be more efficient when $\mathrm{Na}^{+}$and ammonia concentrations are properly adjusted. It is also noteworthy that with high sodium $\left(\mathrm{Na}^{+}\right)$content in Fig. 2, the slope of cumulative hydrogen production against the ammonia concentration in the medium is much more gentle than at lower strength. We believe that no such study on bio-hydrogen generation that considers the complex correlation of nitrogen and salt $\left(\mathrm{Na}^{+}\right)$concentration has been published previously. 
Table 3. Product distribution and recovery ratio on COD basis as a function of the $\mathrm{Na}^{+}$and ammonia concentrations.

\begin{tabular}{|c|c|c|c|c|c|c|c|c|c|c|c|c|c|c|}
\hline \multirow{2}{*}{$\begin{array}{c}\text { Sodium } \\
\left(\mathrm{mg}-\mathrm{Na}^{+} / \mathrm{L}\right)\end{array}$} & \multirow{2}{*}{$\begin{array}{l}\text { Ammonia } \\
(\mathrm{mg}-\mathrm{N} / \mathrm{L})\end{array}$} & \multirow{2}{*}{$\begin{array}{l}\text { Initial } \\
\text { COD }\end{array}$} & \multicolumn{5}{|c|}{ Fatty acid } & \multirow[b]{2}{*}{ Biomass } & \multirow{2}{*}{$\begin{array}{c}\text { Soluble } \\
\text { COD }\end{array}$} & \multirow{2}{*}{$\begin{array}{l}\text { Remaining } \\
\text { carbohydrate }\end{array}$} & \multirow[b]{2}{*}{ Others } & \multirow[b]{2}{*}{$\mathrm{H}_{2}$} & \multirow{2}{*}{$\begin{array}{c}\text { Recovery } \\
(\%)\end{array}$} & \multirow{2}{*}{$\begin{array}{l}\mathrm{B} / \mathrm{A} \\
\text { ratio }\end{array}$} \\
\hline & & & Acetate & $\begin{array}{c}\text { Pro } \\
\text { pionate }\end{array}$ & Formate & Butyrate & Lactate & & & & & & & \\
\hline \multirow[t]{4}{*}{600} & 150 & 100 & 0.32 & N.D. & 0.06 & 0.09 & 0.42 & 7.17 & 90.01 & 9.84 & 79.28 & 2.03 & 99.21 & 0.28 \\
\hline & 200 & 100 & 1.11 & N.D. & N.D & 1.37 & 0.00 & 14.54 & 77.78 & 3.81 & 71.49 & 6.66 & 98.99 & 1.23 \\
\hline & 350 & 100 & 0.88 & N.D & N.D & 2.53 & 1.57 & 16.02 & 75.76 & 6.63 & 64.16 & 8.53 & 100.30 & 2.88 \\
\hline & 600 & 100 & 0.76 & 1.30 & N.D & 1.19 & 0.00 & 13.44 & 81.79 & 2.03 & 76.52 & 4.48 & 99.71 & 1.57 \\
\hline \multirow[t]{4}{*}{1,000} & 200 & 100 & 3.09 & 1.93 & 0.34 & 1.66 & N.D & 15.43 & 88.01 & 2.54 & 78.45 & 4.45 & 107.89 & 0.54 \\
\hline & 600 & 100 & 1.45 & 1.75 & N.D & 1.98 & 0.00 & 15.93 & 85.02 & 3.98 & 75.86 & 6.13 & 107.08 & 1.37 \\
\hline & 1,500 & 100 & 2.61 & 2.46 & 0.29 & 2.15 & 0.00 & 15.49 & 85.21 & 6.47 & 71.23 & 3.23 & 103.93 & 0.82 \\
\hline & 3,000 & 100 & 3.28 & 3.34 & N.D & 2.45 & N.D & 15.55 & 91.41 & 2.77 & 79.57 & 2.79 & 109.76 & 0.75 \\
\hline \multirow[t]{3}{*}{4,000} & 100 & 100 & 2.34 & 1.17 & 0.79 & 1.21 & 0.00 & 19.24 & 81.50 & 9.21 & 66.78 & 3.48 & 104.22 & 0.52 \\
\hline & 200 & 100 & 3.79 & 2.06 & N.D & 1.58 & N.D & 18.84 & 76.92 & 9.03 & 60.46 & 3.59 & 99.35 & 0.42 \\
\hline & 1,500 & 100 & 3.56 & 2.61 & N.D & 3.80 & 2.08 & 14.31 & 84.97 & 5.47 & 67.44 & 3.45 & 102.73 & 1.07 \\
\hline
\end{tabular}

Recovery $=\left(\right.$ soluble $\mathrm{COD}+\mathrm{H}_{2}+$ Biomass $) /$ initial COD $\times 100(\%)$.

\section{Variations of Individual VFAs Concentrations and B/A Ratio}

Acid production is usually accompanied by hydrogen production, which in turn is coupled with the production of solvents, such as ethanol, methanol, butanol, propanol, and acetone. Thus, monitoring of these intermediates reflects the metabolic pathways of microorganisms. Table 3 shows VFA distributions and COD balance in the reactor.

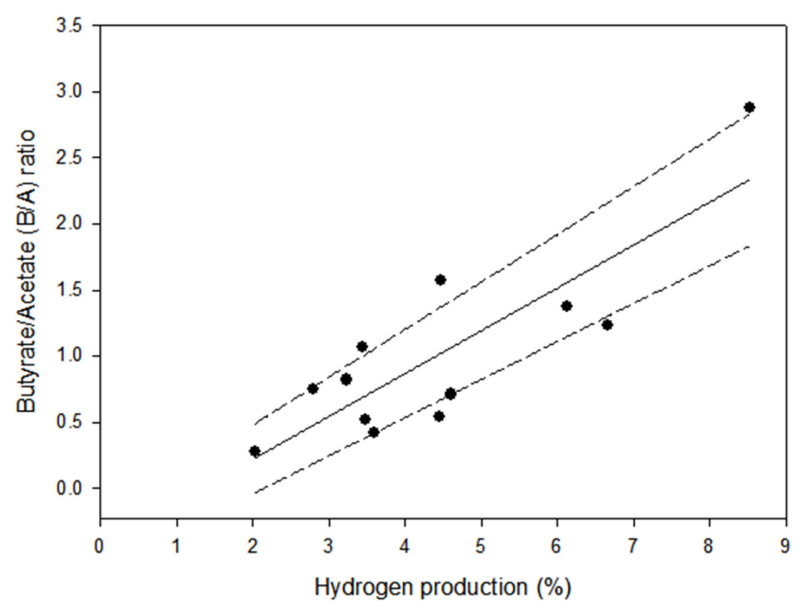

Fig. 3. Changes of $\mathrm{B} / \mathrm{A}$ ratio against the bio-hydrogen production.

Hydrogen production (\%) represents the produced bio-hydrogen gas from the initial substrate concentration (as COD). Regression of experimental data was conducted using Sigma Plot software. B/A ratio $=0.3242 \times$ Hydrogen production $(\%)-0.4297$. (r-square: 0.71 , and $p$-value: 0.0006 Straight line: regression fit, Dotted line: $95 \%$ confidence intervals)
Carbon content in biomass was assumed at $\mathrm{C}_{5} \mathrm{H}_{7} \mathrm{O}_{2} \mathrm{~N}$. Others (\%) in Table 3 mean the soluble COD minus the sum of VFAs and soluble carbohydrate concentration divided by the initial COD concentration, referring to solvent concentrations of products that were not detected by the UV detector by HPLC at $210 \mathrm{~nm}$ after reaction [27, 42]. Initial COD of $10,000 \mathrm{mg} / \mathrm{l}$ was converted to $100 \%$. Values of other compounds are also converted into COD values, and divided by initial COD for recovery calculation. At various concentrations of $\mathrm{Na}^{+}$and ammonia, acetate, butyrate, and propionate were the abundant species. As hydrogen production increased, concentrations of acetate and butyrate increased; in contrast, reduction of hydrogen production resulted in high propionate concentration.

Fig. 3 shows the B/A ratio plotted and analyzed, with hydrogen production. The $\mathrm{B} / \mathrm{A}$ ratio was higher in proportion to bio-hydrogen production $(\mathrm{B} / \mathrm{A}$ ratio $=0.3242 \times$ Hydrogen production (\%) - 0.4297, r-square: 0.71, p-value: 0.0006). Previous studies $[27,43]$ have reported that higher ratio of $\mathrm{B} / \mathrm{A}$, could be more preferable for hydrogen production. The $\mathrm{B} / \mathrm{A}$ ratio change implied a microbial community shift, due to changes of ammonia or $\mathrm{Na}^{+}$concentrations, resulting in lower production of hydrogen. This finding agreed with previous results, that in the presence of high $\mathrm{Na}^{+}$concentration, hydrogen-producing bacteria displaced the fermentation process towards the acetate synthesis pathway, instead of the butyrate pathway [17].

PCR-DGGE Profile Analysis of the Microbial Community

The experimental results suggested that the microbial community changes depending on the $\mathrm{Na}^{+}$and ammonia 


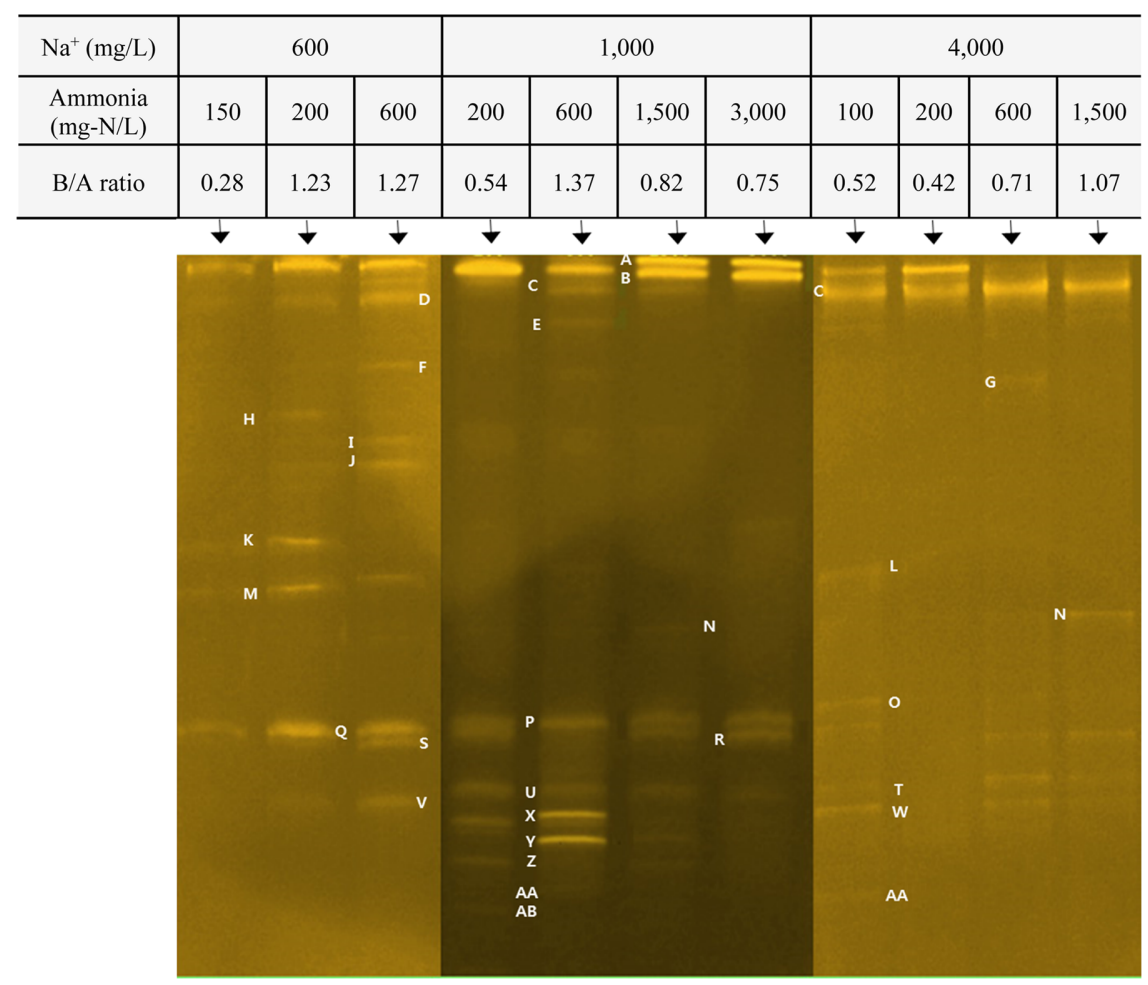

Fig. 4. PCR-DGGE profile of the cultures at various concentrations of $\mathrm{Na}^{+}$and ammonia.

The numbers above the arrow on each lane represent the concentrations of $\mathrm{Na}^{+}$and ammonia, and the $\mathrm{B} / \mathrm{A}$ ratio, respectively.

concentrations determines the changes in hydrogen production activities and acid production. The effect of $\mathrm{Na}^{+}$ and ammonia on the microbial community responsible for bio-hydrogen production was investigated and confirmed by PCR-DGGE analysis on $16 \mathrm{~s}$ rDNA. The relative diversity of the microbial community and the degree of abundance of each microbial group are closely related with the number of bands and the band intensity in the gel, respectively [44]. Fig. 4 shows the PCR-DGGE profiles of each sample, which revealed band patterns in the presence of $\mathrm{Na}^{+}$and ammonia.

Based on the band intensities, in $600 \mathrm{mg}-\mathrm{Na}^{+} / \mathrm{L}$ sodium concentration, bands (B, D, F, H, I, J, K, M, Q, S, and V) are present. In 1,000 $\mathrm{mg}-\mathrm{Na}^{+} / \mathrm{L}$ sodium concentration, bands (A, B, C, E, N, P, Q, R, U, X, Y, Z, AA, and AB) are detected, indicating the existence of various microbial species. In 4,000 $\mathrm{mg}-\mathrm{Na}^{+} / \mathrm{L}$ sodium concentration, bands ( $\mathrm{B}$ and $\mathrm{C}$ ) are clearly evident, while bands (G, L, N, O, T, W, and AA) are dimly visible. In $600 \mathrm{mg}-\mathrm{Na}^{+} / \mathrm{L}$ of sodium concentration, (F, H, I, J, K, M, Q, S, and V) are major bands with relatively high $\mathrm{B} / \mathrm{A}$ ratio, representing high production of biohydrogen. In 1,000 $\mathrm{mg}-\mathrm{Na}^{+} / \mathrm{L}$, bands (C, P, U, X, and $\mathrm{Y}$ ) are predominant, with high $\mathrm{B} / \mathrm{A}$ ratio. In $4,000 \mathrm{mg}-\mathrm{Na}^{+} / \mathrm{L}$, bands ( $\mathrm{N}$ and $\mathrm{R}$ ) are distinguishable with high $\mathrm{B} / \mathrm{A}$ ratio. Taken together, under different $\mathrm{Na}^{+}$concentrations, distinct band patterns with similar B/A ratios are evident. This reveals that each sample has microbial diversity according to the $\mathrm{Na}^{+}$and ammonia profiles, even though it has a similar hydrogen production rate. Bands of interest were sequenced to investigate the microbial diversity among samples. The NCBI BLAST program was used to identify microbes and accession numbers from the 16S rDNA. Table 4 shows the closest affiliation and similarity of the bands on the gradient gel. Three major bacterial taxa were identified, with nine sequences related to the class $\gamma$-Proteobacteria, five affiliated with Bacteria, and fourteen related to the phylum Firmicutes.

Clostridia bacterium, Clostridium saccharobutylicum, Clostridium algidicarnis, Clostridium butyricum, and Clostridium sp. were detected as part of the Clostridium genus. Hydrogenoanaerobacterium sp., Enterococcus sp., Lactococcus lactis, and Lactococcus lactis subsp. lactis were also identified. The Clostridium genus of the phylum Firmicutes showed comparatively high dominance, as shown in Fig. 4 by bands (E, I, M, N, P, V, X, Y, and $A B)$, and had been reported to generate hydrogen gas under the fermentation 
Table 4. The affiliation of DGGE bands as determined by the rDNA sequences.

\begin{tabular}{|c|c|c|c|c|}
\hline \multirow{2}{*}{$\begin{array}{l}\text { Band } \\
\text { name }\end{array}$} & Gen band search result & \multirow{2}{*}{ Accession No. } & \multirow{2}{*}{ Similarity } & \multirow{2}{*}{$\begin{array}{c}\text { Taxonomic description } \\
\text { (Class) }\end{array}$} \\
\hline & Phylogenetically closet relative & & & \\
\hline A & Enterococcus sp. HGB0104 & JX519903.1 & 99 & Firmicutes \\
\hline B & Bacterium NLAE-zl-C199 & JQ607927.1 & 95 & Bacteria \\
\hline C & Uncultured bacterium clone OC2_N15 & КС860573.1 & 98 & Bacteria \\
\hline $\mathrm{D}$ & Lactococcus lactis isolate TIL8 & JX893570.1 & 91 & Firmicutes \\
\hline E & Clostridia bacterium S130(2)-2 & GU136556.1 & 92 & Firmicutess \\
\hline $\mathrm{F}$ & Uncultured bacterium clone 70-1-2 & DQ842542.1 & 100 & Bacteria \\
\hline G & Lactococcus lactis subsp. lactis strain NM151-4 & HM218597.1 & 82 & Firmicutes \\
\hline $\mathrm{H}$ & Klebsiella pneumonia strain ND6 & JF927782.1 & 95 & $\gamma$-proteobacteria \\
\hline I & Clostridium saccharobutylicum DSM 13864 & СР006721.1 & 90 & Firmicutes \\
\hline $\mathrm{J}$ & Enterobacter hormaechei strain LAB 229 & KJ156326.1 & 97 & $\gamma$-proteobacteria \\
\hline K & Enterobacter sp. NCCP-231 & AB610883.1 & 94 & $\gamma$-proteobacteria \\
\hline $\mathrm{L}$ & Uncultured Enterobacteriaceae bacterium clone CSC13DXRNA 24 & KJ624484.1 & 100 & $\gamma$-proteobacteria \\
\hline M & Clostridium algidicarnis strain E107 & JX267120.1 & 86 & Firmicutes \\
\hline $\mathrm{N}$ & Clostridium butyricum strain W5 & DQ831124.1 & 100 & Firmicutes \\
\hline $\mathrm{O}$ & Hydrogenoanaerobacterium sp. YN3 & AB537982.1 & 98 & Firmicutes \\
\hline $\mathrm{P}$ & Uncultured Clostridium sp. clone 8426 & KF508692.1 & 90 & Firmicutes \\
\hline Q & Klebsiella sp. d252 & FJ950657.1 & 86 & $\gamma$-proteobacteria \\
\hline $\mathrm{R}$ & Hydrogenoanaerobacterium sp. YN3 & AB537982.1 & 98 & Firmicutes \\
\hline S & Uncultured bacterium clone B.11 & KF512526.1 & 95 & Bacteria \\
\hline $\mathrm{T}$ & Klebsiella pneumonia strain FY2 & KJ599860.1 & 94 & $\gamma$-proteobacteria \\
\hline $\mathrm{U}$ & Enterobacter sp. 2356 & JX174233.1 & 98 & $\gamma$-proteobacteria \\
\hline $\mathrm{V}$ & Clostridium sp. R6 & EF174500.1 & 91 & Firmicutes \\
\hline W & Klebsiella sp. CCFM8383 & KJ803940.1 & 95 & $\gamma$-proteobacteria \\
\hline$x$ & Clostridium sp. MCF105 & KC155326.1 & 98 & Firmicutes \\
\hline Y & Uncultured Clostridium sp. clone b2-73 & JX575825.1 & 98 & Firmicutes \\
\hline Z & Enterobacter sp. 2358 & JX174235.1 & 99 & $\gamma$-proteobacteria \\
\hline AA & Uncultured bacterium clone GDIC2IK01AKQ69 & JF670002.1 & 85 & Bacteria \\
\hline $\mathrm{AB}$ & Uncultured Clostridium sp. clone T12 & DQ168179.1 & 89 & Firmicutes \\
\hline
\end{tabular}

process [33, 45-48]. The genus in the class $\gamma$-proteobacteria were the Klebsiella and Enterobacter genus, which had also been known as hydrogen-producing bacteria [29]. The Klebsiella genus was shown in Fig. 4 in bands $(\mathrm{H}, \mathrm{Q}, \mathrm{T}$, and $\mathrm{W})$. The Enterobacter genus was also present in bands (J, K, $\mathrm{L}, \mathrm{U}$, and $\mathrm{Z}$ ). They have been reported for hydrogen production [49-54]. Although Enterococcus sp. or Hydrogenoanaerobacterium sp. have been reported as hydrogenproducing microorganisms [55,56], Lactococcus sp., designated as bands (D and G), is known as an inhibitor of hydrogen fermentation [57]. It is known that most of the microbes identified in this study are associated with hydrogen production, except for Lactococcus sp. This study conclusively shows that the interrelations of the ammonia and $\mathrm{Na}^{+}$concentrations change the microbial community in the medium, and consequently show different hydrogen production rates and $\mathrm{B} / \mathrm{A}$ ratios. The analysis of microbial communities with different concentrations of $\mathrm{Na}^{+}$and ammonia shows various diversities for each condition. At $300 \mathrm{mg}-\mathrm{N} / \mathrm{L}$ of ammonia and $600 \mathrm{mg}-\mathrm{Na}^{+} / \mathrm{L}$ sodium concentration, Klebsiella sp., Clostridium sp., and Enterobacter sp. were predominant. At $800 \mathrm{mg}-\mathrm{N} / \mathrm{L}$ of ammonia and $1,000 \mathrm{mg}^{-\mathrm{Na}^{+}} / \mathrm{L}$ sodium concentration, Clostridium sp., and Enterobacter sp. were the most abundant hydrogenproducing bacteria. At 1,500 $\mathrm{mg}-\mathrm{N} / \mathrm{L}$ of ammonia and 4,000 mg- $\mathrm{Na}^{+} / \mathrm{L}$ sodium concentration, Clostridium sp. and Hydrogenoanaerobacterium sp. were the microbes that were most responsible for hydrogen production. 


\section{Acknowledgments}

This work is financially supported by the Korea Ministry of Environment (MOE) as a Knowledge-based environmental service waste to energy recycling human resource development project.

\section{Conflict of Interest}

The authors have no financial conflicts of interest to declare.

\section{References}

1. Khanal SK, Chen WH, Chen LL, Sung S. 2004. Biological hydrogen production: effects of $\mathrm{pH}$ and intermediate products. Int. J. Hydrogen Energy 29: 1123-1131.

2. Huang M, Ouyang L, Wang H, Liu J, Zhu M. 2015. Hydrogen generation by hydrolysis of $\mathrm{MgH}_{2}$ and enhanced kinetics performance of ammonium chloride introducing. Int. J. Hydrogen Energy 40: 6145-6150.

3. Chen W, Ouyang LZ, Liu JW, Yao XD, Wang H, Liu ZW, et al. 2017. Hydrolysis and regeneration of sodium borohydride $\left(\mathrm{NaBH}_{4}\right)$ - a combination of hydrogen production and storage. J. Power Sources 359: 400-407.

4. Ma M, Duan R, Ouyang L, Zhu X, Peng C, Zhu M. 2017. Hydrogen generation via hydrolysis of $\mathrm{H}-\mathrm{CaMg}_{2}$ and $\mathrm{H}$ $\mathrm{CaMg}_{1.9} \mathrm{Ni}_{0.1}$. Int. J. Hydrogen Energy 42: 22312-22317.

5. Kapdan IK, Kargi F. 2006. Bio-hydrogen production from waste materials. Enzyme Microb. Technol. 38: 569-582.

6. Adamson KA. 2004. Hydrogen from renewable resourcesthe hundred year commitment. Energ. Policy 32: 1231-1242.

7. Kotay SM, Das D. 2008. Biohydrogen as a renewable energy resource-prospects and potentials. Int. J. Hydrogen Energy 33: 258-263.

8. Nath K, Das D. 2004. Improvement of fermentative hydrogen production: various approaches. Appl. Microbiol. Biotechnol. 65: 520-529.

9. Das D, Veziroğlu TN. 2001. Hydrogen production by biological processes: a survey of literature. Int. J. Hydrogen Energy 26: 13-28.

10. Hawkes FR, Hussy I, Kyazze G, Dinsdale R, Hawkes DL. 2007. Continuous dark fermentative hydrogen production by mesophilic microflora: principles and progress. Int. J. Hydrogen Energy 32: 172-184.

11. Oh YK, Seol EH, Lee EY, Park SH. 2002. Fermentative hydrogen production by a new chemoheterotrophic bacterium Rhodopseudomonas palustris P4. Int. J. Hydrogen Energy 27: 1373-1379.

12. Liu X, Zhu Y, Yang ST. 2006. Butyric acid and hydrogen production by Clostridium tyrobutyricum ATCC 25755 and mutants. Enzyme Microb. Technol. 38: 521-528.
13. Campoy RA, Guelfo LAF, Fallego CJA, Garcia LIR. 2017. Inhibition of the hydrolytic phase in the production of biohydrogen by dark fermentation of organic solid waste. Energy Fuels 31: 7176-7184

14. Sivagurunathan $P$, Kumar G, Bakonyi P, Kim SH, Kobayashi $\mathrm{T}, \mathrm{Xu} \mathrm{KQ}$, et al. 2016. A critical review on issues and overcoming strategies for the enhancement of dark fermentative hydrogen production in continuous systems. Int. J. Hydrogen Energy 41: 3820-3836.

15. Xiaolong H, Minghua Z, Hanqing Y, Qinqin S, Lecheng L. 2006. Effect of sodium ion concentration on hydrogen production from sucrose by anaerobic hydrogen-producing granular sludge. Chinese J. Chem. Eng. 14: 511-517.

16. Sprott GD, Shaw KM, Jarrell KF. 1984. Ammonia/potassium exchange in methanogenic bacteria. J. Biol. Chem. 259: 1260212608 .

17. Lee MJ, Kim TH, Min BK, Hwang SJ. 2012. Sodium $\left(\mathrm{Na}^{+}\right)$ concentration effects on metabolic pathway and estimation of ATP use in dark fermentation hydrogen production through stoichiometric analysis. J. Environ. Manage 108: 22-26.

18. Jin B, Wang S, Xing L, Li B, Peng Y. 2016. The effect of salinity on waste activated sludge alkaline fermentation and kinetic analysis. J. Environ. Sci. 43: 80-90.

19. Kim DH, Kim SH, Shin HS. 2009. Sodium inhibition of fermentative hydrogen production. Int. J. Hydrogen Energy 34: 3295-3304.

20. Salerno MB, Park WS, Zuo Y, Logan BE. 2006. Inhibition of biohydrogen production by ammonia. Water Res. 40: 1167-1172.

21. Wang B, Wan W, Wang J. 2009. Effect of ammonia concentration on fermentative hydrogen production by mixed cultures. Bioresour. Technol. 100: 1211-1213.

22. Kumar P, Sharma R, Ray S, Mehariya S, Patel SKS, Lee JK, et al. 2015. Dark fermentative bioconversion of glycerol to hydrogen by Bacillus thuringiensis. Bioresour. Technol. 182: 383-388

23. Kadam PC, Boone DR. 1996. Influence of $\mathrm{pH}$ on ammonia accumulation and toxicity in halophilic, methylotrophic methanogens. Appl. Environ. Microbiol. 62: 4486-4492.

24. $\mathrm{Wu} \mathrm{JH}$, Lin CY. 2004. Biohydrogen production by mesophilic fermentation of food wastewater. Water Sci. Technol. 49: 223-228.

25. Lin CY, Lay CH. 2004. Carbon/nitrogen-ratio effect on fermentative hydrogen production by mixed microflora. Int. J. Hydrogen Energy 29: 41-45.

26. Kang JH, Kim D, Lee TJ. 2012. Hydrogen production and microbial diversity in sewage sludge fermentation preceded by heat and alkaline treatment. Bioresour. Technol. 109: 239-243.

27. Jun YS, Yu SH, Ryu KG, Lee TJ. 2008. Kinetic study of pH effects on biological hydrogen production by a mixed culture. J. Microbiol. Biotechnol. 18: 1130-1135.

28. Arnold EG, Lenore SC, Andrew DE. 1992. pp. 56-59. American Public Health Association. Standard methods for the examination of water and wastewater, $18^{\text {th }}$ Ed. American Public Health Assoc. Washington, DC, USA. 
29. Michel DB, Gilles KA, Hamilton JK, Rebers PA, Smith F. 1956. Colorimetric method for determination of sugars and related substances. Anal. Chem. 28: 350-356.

30. Markwell MAK, Haas SM, Bieber LL, Tolbert NE. 1978. A modification of the lowry procedure to simplify protein determination in membrane and lipoprotein samples. Anal. Biochem. 87: 206-210.

31. Muyzer G, Waal EC, Uitterlinden AG. 1993. Profiling of complex microbial populations by denaturing gradient gel electrophoresis analysis of polymerase chain reaction-amplified genes coding for 16S rRNA. Appl. Environ. Microbiol. 59: 695700 .

32. Pedro MS, Haruta S, Hazaka M, Shimada R, Yoshida C, Hiura $\mathrm{K}$, et al. 2001. Denaturing gradient gel electrophoresis analyses of microbial community from field-scale composter. J. Biosci. Bioeng. 91: 159-165.

33. Baek JS, Choi EH, Yun YS, Kim SC, Kim MS. 2006. Comparison of hydrogenases from Clostridium butyricum and Thiocapsa roseopersicina: hydrogenases of C. butyricum and T. roseopersicina. J. Microbiol. Biotechnol. 16: 1210-1215.

34. Cao X, Zhao Y. 2009. The influence of sodium on biohydrogen production from food waste by anaerobic fermentation. J. Mater. Cycles Waste Manage. 11: 244-250.

35. Thakur V, Jadhav SK, Tiwari KL. 2014. Optimization of different parameters for biohydrogen production by Klebsiella oxytoca ATCC 13182. Trends Appl. Sci. Res. 9: 229-237.

36. Xu J, Marc MA. 2015. Fermentation of swine wastewaterderived duckweed for biohydrogen production. Int. J. Hydrogen Energy 40: 7028-7036.

37. Yenigün O, Demirel B. 2013. Ammonia inhibition in anaerobic digestion: a review. Process Biochem. 48: 901-911.

38. Kayhanian M. 1999. Ammonia inhibition in high-solids biogasification: an overview and practical solutions. Environ. Technol. 20: 355-365.

39. Härtel U, Buckel W. 1996. Sodium ion-dependent hydrogen production in Acidaminococcus fermentans. Arch. Microbiol. 166: 350-356.

40. Brüggemann $H$, Bäumer S, Fricke WF, Wiezer A, Liesegang $\mathrm{H}$, Decker I, et al. 2003. The genome sequence of Clostridium tetani, the causative agent of tetanus disease. Proc. Natl. Acad. Sci. USA 100: 1316-1321.

41. Boiangiu CD, Jayamani E, Brügel D, Herrmann G, Kim J, Forzi L, et al. 2005. Sodium ion pumps and hydrogen production in glutamate fermenting anaerobic bacteria. $J$. Mol. Microbiol. Biotechnol. 10: 105-119.

42. Show KY, Zhang ZP, Tay JH, Liang DT, Lee DJ, Jiang WJ. 2007. Production of hydrogen in a granular sludge-based anaerobic continuous stirred tank reactor. Int. J. Hydrogen Energy 32: 4744-4753.

43. Kim SH, Han SK, Shin HS. 2006. Effect of substrate concentration on hydrogen production and 16S rDNA-based analysis of the microbial community in a continuous fermenter. Process Biochem. 41: 199-207.
44. Zhang T, Fang HHP. 2000. Digitization of DGGE (denaturing gradient gel electrophoresis) profile and cluster analysis of microbial communities. Biotechnol. Lett. 22: 399-405.

45. Bomar M, Hippe H, Schink B. 1991. Lithotrophic growth and hydrogen metabolism by clostridium magnum. FEMS Microbiol. Lett. 83: 347-350.

46. Wang X, Hoefel D, Saint CP, Monis PT, Jin B. 2007. The isolation and microbial community analysis of hydrogen producing bacteria from activated sludge. J. Appl. Microbiol. 103: 1415-1423.

47. Chang JJ, Chen WE, Shih SY, Yu SJ, Lay JJ, Wen FS, et al. 2006. Molecular detection of the clostridia in an anaerobic biohydrogen fermentation system by hydrogenase mRNAtargeted reverse transcription-PCR. Appl. Microbiol. Biotechnol. 70: 598-604.

48. Hung $\mathrm{CH}$, Cheng $\mathrm{CH}$, Cheng LH, Liang CM, Lin CY. 2008. Application of clostridium-specific PCR primers on the analysis of dark fermentation hydrogen-producing bacterial community. Int. J. Hydrogen Energy 33: 1586-1592.

49. Minnan L, Jinli H, Xiaobin W, Huijuan X, Jinzao C, Chuannan $\mathrm{L}$, et al. 2005. Isolation and characterization of a high $\mathrm{H}_{2}$-producing strain klebsiella oxytoca HP1 from a hot spring. Res. Microbiol. 156: 76-81.

50. Sivagurunathan P, Kumar G, Park JH, Park JH, Park HD, Yoon JJ, et al. 2016. Feasibility of enriched mixed cultures obtained by repeated batch transfer in continuous hydrogen fermentation. Int. J. Hydrogen Energy 41: 4393-4403.

51. Chen X, Sun Y, Xiu Z, Li X, Zhang D. 2006. Stoichiometric analysis of biological hydrogen production by fermentative bacteria. Int. J. Hydrogen Energy 31: 539-549.

52. Hitit ZY, Lazaro CZ. Hallenbeck PC. 2017. Hydrogen production by co-cultures of Clostridium butyricum and Rhodospeudomonas palustris: optimization of yield using response surface methodology. Int. J. Hydrogen Energy 42: 6578-6589.

53. Long C, Cui J, Liu Z, Liu Y, Long M, Hu Z. 2010. Statistical optimization of fermentative hydrogen production from xylose by newly isolated Enterobacter sp. CN1. Int. J. Hydrogen Energy 35: 6657-6664.

54. Maru BT, López F, Kengen SWM, Constantí M, Medina F. 2016. Dark fermentative hydrogen and ethanol production from biodiesel waste glycerol using a co-culture of Escherichia coli and Enterobacter sp. Fuel 186: 375-384.

55. Yin Y, Wang J. 2016. Characterization and hydrogen production performance of a novel strain Enterococcus faecium INET2 isolated from gamma irradiated sludge. Int. J. Hydrogen Energy 41: 22793-22801.

56. Song L, Dong X. 2009. Hydrogenoanaerobacterium saccharovorans gen. nov., sp. nov., isolated from $\mathrm{H}_{2}$-producing UASB granules. Int. J. Syst. Evol. Microbiol. 59: 295-299.

57. Noike T, Takabatake H, Mizuno O, Ohba M. 2002. Inhibition of hydrogen fermentation of organic wastes by lactic acid bacteria. Int. J. Hydrogen Energy 27: 1367-1371. 